\title{
Plants from Ulleung island ameliorate lipid accumulation and oxidative stress in oleic acid-induced in HepG2 Cells
}

\author{
SukJin $\mathrm{Kim}^{1}$, Gun-Hee $\mathrm{Kim}^{1,2 *}$ \\ ${ }^{1}$ Department of Bio-Health Convergence Major, Duksung Women's University, Seoul 01369, Korea \\ ${ }^{2}$ Department of Food and Nutrition, Duksung Women's University, Seoul 01369, Korea
}

\section{울릉도산 식물의 HepG2 세포에서 지질 축적 및 산화 스트레스 개선 효과

\author{
김숙진 ${ }^{1} \cdot$ 김건희 $^{1,2 *}$ \\ ${ }^{1}$ 덕성여자대학교 바이오헬스융합학과, ${ }^{2}$ 덕성여자대학교 식품영양학과
}

\begin{abstract}
Oxidative stress can directly damage lipids, proteins, and DNA, which promotes the progression from steatosis to nonalcoholic fatty liver disease. This study aimed to determine the antioxidative effects of Campanula takesimana Nakai, Ilex integra THUNB., Indigofera pseudotinctoria Matsum., Rubus takesimensis Nakai, and Tsuga sieboldii from Ulleung Island and their ability to inhibit lipid accumulation in HepG2 cells. The total phenolics (TPC) and flavonoid (TFC) contents of extracts of the five plants were determined, and their antioxidative activities were analyzed using DPPH and $\mathrm{ABTS}$ radical scavenging ability, $\mathrm{Fe}^{2+}$ reducing capacity (FRAP), oxygen radical absorbance capacity (ORAC), and thiobarbituric acid assays. Lipid accumulation was evaluated by Oil Red $O$ staining and intracellular triglyceride (TG) assays. Rubus takesimensis Nakai had the highest TPC among the five plants. The antioxidant activity of $R$. Nakai was $D P P H\left(I_{50}=0.30 \mathrm{mg} / \mathrm{mL}\right)$, ABTS $\left(\mathrm{IC}_{50}=0.33 \mathrm{mg} / \mathrm{mL}\right)$, FRAP $(318.61 \mu \mathrm{mol} \mathrm{FeSO} / \mathrm{g})$, and ORAC $(1.74 \mu \mathrm{mol} \mathrm{TE} / \mathrm{g})$. The lipid peroxidation inhibitory effect of $R$. Nakai was reduced to $52.51 \%$ at $1 \mathrm{mg} / \mathrm{mL}$. Incubating HepG2 cells with extracts of the five plants reduced lipid and TG accumulation by $>50 \%$, and inhibited lipid peroxidation by $\sim 19 \%$. These results provided evidence for the development of functional foods based on these five plants from Ulleung Island, due to their antioxidant activities and ability to reduce lipid accumulation.
\end{abstract}

Key words : Ulleung island plant, antioxidant, lipid accumulation, lipid peroxidation, HepG2

\section{서 론}

울릉도는 $80 \%$ 가 화산암으로 이루어져 있고, 온대 해양성 기후로 토양과 기후 조건이 한반도 내륙과 크게 달라 해양 식물에서 고산 식물에 이르기까지 700여 종 이상의 식물이 서식하고 있다고 보고되었다(Yang 등, 2015). 울릉도 식물은 영양적인 면이나 기호적인 면에서 중요성이 인식되지 않았으
나, 국민 소득 수준의 향상과 더불어 식생활의 양상이 점차 다양화되면서 최근 섭취량이 증가하고 있으며, 채소류를 비 롯한 다양한 식물의 항산화, 항암 및 항진균성과 같은 생리학 적 기능성에 대한 연구로 관심이 증가되고 있다(Kang 등, 2010; Kim 등, 2013). 울릉도산 식물 중 재배학적으로 많이 연구되어 종의 유지에 문제가 없으며, 앞으로의 개발 가능성 이 높은 소재 5 종을 선정하였다. 실험에 사용한 울릉도산 5 종

*Corresponding author. E-mail : ghkim@duksung.ac.kr, Phone : +82-2-901-8496, Fax : +82-2-901-8661

Received 22 July 2020; Revised 13 September 2020; Accepted 14 September 2020.

Copyright (c) The Korean Society of Food Preservation.

This is an Open Access article distributed under the terms of the Creative Commons Attribution Non-Commercial License (http://creativecommons.org/licenses/by-nc/4.0) which permits unrestricted non-commercial use, distribution, and reproduction in any medium, provided the original work is properly cited. 
식물, 섬초롱꽃(Campanula takesimana Nakai) 감탕나무(Ilex integra Thunb.), 낭아초(Indigofera pseudotinctoria Matsum.), 섬나무딸기(Rubus takesimensis Nakai) 및 솔송나무(Tsuga sieboldii)는 폴리페놀 성분이 밝혀졌으나, 생리학적 기능성에 대한 연구가 거의 이루어지지 않았다(Chan 등, 2011; Herrick 과 Perry, 1997; Yang과 Park, 2006). 특히 섬초롱꽃은 종자번 식이 용이하여 일찍이 재배작물화 되었으며, 감탕나무와 낭아 초 역시 재배학적인 연구와 동시에 flavonoid 성분이 자세히 보고되었다(Cho 등, 2007; Kwon 등, 2000; Park 등, 2019).

ROS(reactive oxygen species; 활성산소종)은 에너지 대사 에 산소를 이용하는 모든 생명체에서 생성되는 부산물로, 호 흡 시 체내에 들어오는 산소의 2-3\%는 완전히 산화하지 못하 고 활성 산소가 된다(Shimokawa, 2020). ROS의 과생성은 세포 구조와 만성 감염에 영향을 미쳐 산화 스트레스를 유발 할 수 있으며, 이는 심혈관질환, 당뇨병, 골다공증, 뇌졸증, 신경 퇴화 및 세포 노화 등 각종 질병을 유발한다(Alfadda과 Sallam, 2012). 따라서 superoxide anion radical( $\left(\mathrm{O}_{2}{ }^{-}\right)$, hydroxyl radical $(\cdot \mathrm{OH})$, singlet oxygen $\left(\mathrm{O}_{2}\right)$ 및 hydrogen peroxide $\left(\mathrm{H}_{2} \mathrm{O}_{2}\right)$ 등 과 같은 반응성이 매우 큰 활성 산소(active oxygen)의 제거 에 대한 관심이 높아지고 있다. 오랫동안 전 세계적으로 사용 되어 온 합성 항산화제의 효력은 매우 우수하나 체내 에너지 생산과 세포 대사 및 호흡 작용을 방해하며 발암성이 있고 독 성이 강하다는 문제점이 보고되고 있다(Kahl과 Kappus, 1993). 따라서 vitamin E, tannin, anthocyanin, carotenoid류, flavonoid류 등의 식물 기원의 천연 항산화제의 개발이 절실 히 요구되고 있다.

한편, 간에서 인슐린 저항성이 심해지거나 지방의 간 조직 내 침착이 일어나면 염증 반응이 일어나고, 이는 지방의 과산 화를 일으켜 산화 스트레스를 증가시킨다(Cichoz과 Michalak, 2017). 산화 스트레스의 과도한 증가는 간 조직 내 섬유화를 일으키며, DNA 파괴, 단백질 기능 상실, 지방간 염 또는 지 질 축적으로 인한 중증 지방간을 일으킨다(Jadaja 등, 2017). 간세포에서 지질의 축적은 항산화 시스템의 균형을 파괴시켜 산화적 스트레스를 유발하고, MEOS계인 cytochrome P450 2E1(CYP2E1)에 의해 활성 산소를 생성한다. 그 결과로 지질 과산화, 간세포 재생 지연, 미토콘드리아 기능 저하 등 다양 한 간 기능 장애와 질환을 일으킨다(Spahis 등, 2017). 최근 연구에 따르면 폴리페놀 및 플라보노이드의 항산화 효과에 의한 간 효소 수치의 호전뿐 아니라, 간세포에서 지질 축적 억제, 비알코올성 지방 간염의 조직학적 호전 및 섬유화의 호 전이 보고된 바 있다(Abenavoli 등, 2017).

따라서 본 연구에서는 울릉도산 식물 5 종인 섬초롱꽃, 감 탕나무, 낭아초, 섬나무딸기 및 솔송나무에 대하여 폴리페놀 및 플라보노이드 함량과 그에 따른 항산화 활성 차이를 분석
하였다. 그리고 HepG2 세포에서의 지질 축적 억제 효과 및 지질 과산화물 생성 억제 효과를 검증하고, 천연물 소재로서 식품 활용을 위한 기초 자료를 제공하고자 하였다.

\section{재료 및 방법}

\section{실험재료}

실험에 사용된 울릉도산 식물 5 종인 섬초롱꽃, 감탕나무, 낭아초, 섬나무딸기 및 솔송나무는 전체 부위를 건조한 시료 를 국립수목원으로부터 분양받아 사용하였다. 2,2'-azobis (2-amidino-propane)dihydrochloride(AAPH), 1,1-diphenyl-2picryl-hydrazyl(DPPH), 2,2-azino-bis(3-ethylbenzothiazoline6-sulfonic acid(ABTS), potassium persulfate, sodium phosphate, ferric chloride $\left(\mathrm{FeCl}_{3}\right)$, sodium acetate, 4,6-tripryridylstriazine, ascorbic acid, dimethyl sulfoxide(DMSO) 및 3-(4,5-dimethylthiazol-2-yl)-2,5-dimethyltetrazolium bromide(MTT) 등 그 외 모든 시약은 Sigma-Aldrich(Sigma-Aldrich, MO, USA)로부터 구입하였다. 세포 배양에 필요한 Dulbecco's modified eagle's medium(DMEM) 배지 및 fetal bovine serum(FBS)은 Welgene(Welgene, Daegu, Korea)에서 구입하 였다.

\section{추출물 제조}

울릉도산 식물 5 종은 시료 $10 \mathrm{~g}$ 당 10 배량 $(\mathrm{w} / \mathrm{v})$ 의 $70 \%$ 에 탄올로 3 시간 동안 3 회 환류 추출하고, 추출액은 여과지 (Whatman, Middlesex, UK)로 여과하였다. 여과된 추출액은 $50^{\circ} \mathrm{C}$ 수욕상에서 rotary vacuum evaporator(EYELA N-1000, Riakikiai Co., Ltd., Tokyo, Japan)로 용매를 제거하고, 감압, 농축한 후 동결 건조하여 추출 수율을 계산하였다. 건조된 시 료는 3차 증류수에 $200 \mathrm{mg} / \mathrm{mL}$ 로 녹여 $-70^{\circ} \mathrm{C}$ 에 저장하였다 가 3 차 증류수를 이용하여 실험에 적정 농도로 희석하여 사 용하였다.

\section{총폴리페놀 및 총플라보노이드 함량}

총폴리페놀 함량은 Folin-Denis 방법을 변형하여 측정하였 다(Ainsworth과 Gillespie, 2007). $0.2 \mathrm{mg} / \mathrm{mL}$ 농도의 추출물 $50 \mu \mathrm{L}$ 에 Folin-Ciocalteu's phenol reagent $50 \mu \mathrm{L}$ 를 첨가한 후 3 분간 실온에서 반응시켰다. 반응액에 $2 \%$ sodium carbonate $\left(\mathrm{Na}_{2} \mathrm{CO}_{3}\right)$ 용액 $150 \mu \mathrm{L}$ 를 가하여 암실에서 2시간 동안 방치한 후 상등액을 ELISA plate reader(Model 680, Bio-Rad La-boratories, Inc., Tokyo, Japan)를 사용하여 760 $\mathrm{nm}$ 에서 흡광도를 측정하였다. Gallic acid equivalent(GAE) 를 이용하여 표준 곡선을 작성한 후 이 검량 곡선으로부터 시료의 총폴리페놀 함량을 구하였다. 
총플라보노이드 함량은 Shi 등(2019)의 방법에 따라 농도 별로 제조한 추출물 $20 \mu \mathrm{L}$ 에 diethylene glycol $200 \mu \mathrm{L}$ 와 1 $\mathrm{N} \mathrm{NaOH} 20 \mu \mathrm{L}$ 를 순서대로 첨가하여 $37^{\circ} \mathrm{C}$ 에서 1 시간 동안 반응시켰다. 반응액을 $420 \mathrm{~nm}$ 에서 흡광도를 측정하였으며, naringin equivalent(NAE)를 이용하여 표준 곡선을 작성한 후 이 검량 곡선으로부터 시료의 총플라보노이드 함량을 구 하였다.

\section{$\mathrm{DPPH}$ radical 소거능 측정}

울릉도산 식물의 DPPH radical 소거능 측정은 Olszowy와 Dawidoxicz(2018)의 방법을 활용하였다. 각 추출물을 농도 별 $(0.0625,0.125,0.25,0.5,1.0$ 및 $2.0 \mathrm{mg} / \mathrm{mL})$ 로 제조한 시 료 $50 \mu \mathrm{L}$ 에 $0.3 \mathrm{mM} \mathrm{DPPH} 150 \mu \mathrm{L}$ 를 가하고, vortex mixing 후 실온에서 30 분간 반응시킨 후 $517 \mathrm{~nm}$ 에서 흡광도를 측정 하였다. 양성대조군으로 L-ascorbic acid를 사용하였다. 시료 무첨가구와 첨가구의 값을 비교하여 free radical 소거활성을 결정하였으며, 시료 무첨가구의 값을 $50 \%$ 감소시키는 추출 물의 $\mathrm{IC}_{50}(\mathrm{mg} / \mathrm{mL})$ 값으로 나타냈다.

\section{ABTS radical 소거능 측정}

ABTS radical 소거능 측정은 Olszowy와 Dawidoxicz (2018)의 방법을 변형하여 측정하였다. $7.4 \mathrm{mM} \mathrm{ABTS}$ 와 2.6 $\mathrm{mM}$ potassium persulfate를 혼합하여 어두운 곳에 24시간 방 치시킨 후, 이를 $734 \mathrm{~nm}$ 에서 흡광도 값이 $0.7 \pm 0.002$ 가 되도록 phosphate buffered saline(PBS)으로 희석한 ABTS solution을 사용하였다. $0.0625,0.125,0.25,0.5,1.0$ 및 $2.0 \mathrm{mg} / \mathrm{mL}$ 농 도의 시료 용액 $20 \mu \mathrm{L}$ 와 ABTS solution $180 \mu \mathrm{L}$ 를 암소에서 10 분간 반응시킨 후 $732 \mathrm{~nm}$ 에서 흡광도를 측정하여 $\mathrm{IC}_{50}$ $(\mathrm{mg} / \mathrm{mL})$ 값으로 나타냈으며, 양성대조군으로 ascorbic acid 를 사용하였다.

\section{FRAP assay}

FRAP법에 의한 항산화 활성은 Benzie와 Strain의 방법에 따라 $0.3 \mathrm{mM}$ sodium acetate buffer(pH 3.6), $40 \mathrm{mM} \mathrm{HCl}$ 에 용해한 $10 \mathrm{mM} \mathrm{TPTZ(2,4,6-tripyridyl-s-triazine)} \mathrm{용액} \mathrm{및} 20$ $\mathrm{mM}$ ferric chloride를 각각 $10: 1: 1(\mathrm{v} / \mathrm{v} / \mathrm{v})$ 의 비율로 혼합하여 FRAP 기질액으로 사용하였다(Vijalakshm과 Ruckmani, 2016). 96-well plate에 시료 $50 \mu \mathrm{L}$ 와 FRAP 기질 액 $150 \mu \mathrm{L}$ 암소에 서 20 분간 반응시킨 후 $593 \mathrm{~nm}$ 에서 흡광도를 측정하였다. Ferrous sulfate를 표준 물질로 하여 얻은 표준 검량선으로부 터 계산하였으며, 양성대조군 시료로 ascorbic acid를 사용하 였다.

\section{ORAC assay}

울릉도산 식물 추출물의 oxygen radical absorbance capacity
(ORAC) 측정은 Garrett 등(2010)의 방법을 변형하여 사용하 였다. 시료, 표준 용액 또는 양성대조군 시료인 ascorbic acid $25 \mu \mathrm{L}$ 와 $40 \mathrm{nM}$ fluorescein $150 \mu \mathrm{L}$ 를 혼합하고 $37^{\circ} \mathrm{C}$ 에서 3 분간 교반 후, 10 분간 방치시켰다. 이 혼합 용액에 $150 \mathrm{mM}$ 의 $\mathrm{AAPH} 25 \mu \mathrm{L}$ 를 첨가한 뒤 형광 광도계(Tecan Infinite M200, San Jose, CA, USA)로 90분간 3분 간격으로 측정하 였다. 형광 광도계의 excitation은 $485 \mathrm{~nm}$, emission은 520 $\mathrm{nm}$ 로 설정하였다. 결과 값은 시료 무첨가구와 첨가구의 area under curve(AUC) 값을 나타낸 후, 표준물질인 trolox equivalent(TE)를 이용하여 표준 검량 곡선에 대입하여 나타 냈다.

\section{TBA assay}

울릉도산 식물 추출물의 지질 과산화 측정은 Dissanayake 등(2009)의 thiobarbituric acid(TBA) assay를 변형하여 사용 하였다. 농도별 $(0.0625,0.125,0.25,0.5$, 및 $1.0 \mathrm{mg} / \mathrm{mL})$ 시 료와 $10 \mathrm{mM}$ linolenic acid를 혼합한 후에 $37^{\circ} \mathrm{C}$ 에서 1 시간 반응시켰다. 반응물에 $0.05 \mathrm{M} \mathrm{H}_{2} \mathrm{O}_{2}$ 와 $0.05 \mathrm{M} \mathrm{FeSO}_{4}$ 첨가하 고 $37^{\circ} \mathrm{C}$ 에서 2 시간 동안 반응시킨 후, $0.4 \% \mathrm{TBA}$ 를 첨가하여 $95^{\circ} \mathrm{C}$ water bath에서 15 분 동안 반응시켰다. 그 후 $15: 1$ 비율 의 $n$-butanol:pyridine 용액을 $500 \mu \mathrm{L}$ 를 첨가하고 $1,000 \times g$, 10 분 원심 분리 후 상등액을 $532 \mathrm{~nm}$ 에서 흡광도를 측정하였 다. 지질 과산화 억제능은 다음 식으로 산출하였으며 ascorbic $\mathrm{acid}$ 를 양성대조군 시료로 사용하였다.

Lipid peroxidation inhibition $(\%)=(\mathrm{A}-\mathrm{B}) / \mathrm{A} \times 100$ $\mathrm{A}$ : 시료가 무첨가 된 반응물의 흡광도

$\mathrm{B}$ : 시료 첨가된 반응물의 흡광도

\section{HepG2 세포 배양}

인간 간암 세포주 HepG2(Human hepatocellular carcinoma cell line) 세포는 한국세포주은행에서 분양받아 사용하였으 며, $10 \% \mathrm{FBS}, 1 \%$ Anti-biotic Anti-mycotic을 포함한 DMEM 배지를 사용하여 $37^{\circ} \mathrm{C}, 5 \% \mathrm{CO}_{2}$ 조건에서 배양하였다 $(\mathrm{Um}$ 과 $\mathrm{Kim}, 2016)$. 세포는 2 일마다 계대 배양하여 적정수의 세포를 유지하였다.

\section{MTT assay}

울릉도산 식물 5 종의 세포 내 독성을 확인하기 위하여 MTT assay를 이용해 HepG2 세포에 대한 세포 생존율을 측 정하였다(Senthilraja과 Kathiresan, 2015). 배양시킨 HepG2 세포를 $1 \times 10^{5}$ cells $/ \mathrm{mL}$ 의 농도로 96-well plate에 분주하고, 24시간 배양 후, 각 well에 시료를 각각 $0.1,0.2,0.4$ 및 0.8 $\mathrm{mg} / \mathrm{mL}$ 로 첨가하였다. 24시간 처리 후 PBS에 녹인 MTT 용 액 $5 \mathrm{mg} / \mathrm{mL}$ 를 각 well에 $20 \mu \mathrm{L}$ 씩 처리한 후, 4시간 동안 
$37^{\circ} \mathrm{C}, 5 \% \mathrm{CO}_{2}$ 조건에서 배양하였다. 이후 상등액을 제거하 고, $\mathrm{DMSO}$ 를 $100 \mu \mathrm{L}$ 씩 각 well에 첨가하여 생성된 formazan 결정을 용해한 후, $540 \mathrm{~nm}$ 에서 흡광도를 측정하였다. 세포 생존율은 다음 식으로 산출하였다.

Cell viability $(\%)=\mathrm{B} / \mathrm{A} \times 100$
$\mathrm{A}$ : Control의 흡광도
$\mathrm{B}$ : 시료 처리 세포의 흡광도

\section{Oil red 0 staining}

$\mathrm{HepG} 2$ 세포 배양에서 생성된 총 지질 축적량은 Oil Red $\mathrm{O}(\mathrm{ORO})$ 염색법을 통해 측정하였다(Um과 $\mathrm{Kim}, 2016)$. 배양 시킨 HepG2 세포를 $1 \times 10^{6}$ cells $/ \mathrm{mL}$ 의 농도로 6-well plate에 분주하고, 24 시간 배양 후 각 well에 $0.2 \mathrm{mg} / \mathrm{mL}$ 시료 및 ascorbic와 $0.6 \mathrm{mM}$ oleic acid $(\mathrm{OA})$ 를 처리한 후 24시간 배양 시켰다. 분화 유도된 $\mathrm{HepG} 2$ 세포의 배양액을 제거하고, PBS 로 2 회 세척하였다. 세포 고정을 위해 각 well에 $3.7 \%$ formaldehyde $2 \mathrm{~mL}$ 를 넣고 15 분 후 formaldehyde를 제거하 고, PBS로 3번 세척하였다. ORO 염색약은 증류수와 $6: 4$ 의 비율로 섞은 후 $0.2 \mu \mathrm{m}$ filter로 여과하여 사용하였다. 각 well 에 $\mathrm{ORO}$ 용액을 $500 \mu \mathrm{L}$ 씩 넣고, 상온에서 30 분간 염색한 후 PBS로 3번 세척하였다. 염색된 세포 내 지방구(lipid drop)는 현미경으로 관찰하였다. 관찰 후 각 well 당 $1 \mathrm{~mL}$ 의 2-propanol을 넣어 염색약을 추출한 후 $540 \mathrm{~nm}$ 에서 흡광도 를 측정하였으며, ascorbic acid를 양성대조군으로 사용했다.

\section{Triglyceride assay}

HepG2 세포에서 생성된 중성 지방 함량은 triglyceride-S kit(Asan Pharm. Co., Ltd., Seoul, Korea)를 이용하여 측정하 였다. 배양시킨 $\mathrm{HepG} 2$ 세포를 $1 \times 10^{6}$ cells $/ \mathrm{mL}$ 의 농도로 6-well plate에 분주하고 24시간 배양 후, 각 well에 0.2 $\mathrm{mg} / \mathrm{mL}$ 시료와 $0.6 \mathrm{mM} \mathrm{OA}$ 를 처리한 후 24시간 배양시켰다. 분화 유도된 세포는 PBS로 3회 세척하고, scraper로 회수 후, $10,000 \mathrm{rpm}$ 에서 5 분간 원심 분리하였다. 원심 분리 후 상층 액을 제거하고, pellet에 lysis buffer(Tris-EDTA buffer)를 첨 가하여 $4^{\circ} \mathrm{C}, 12,000 \mathrm{rpm}$ 에서 원심 분리하였다. 회수한 상층 액 $80 \mu \mathrm{L}$ 에 $120 \mu \mathrm{L}$ 의 enzyme buffer solution을 첨가하여 혼합한 다음, $37^{\circ} \mathrm{C}$ 에서 20 분간 반응시킨 후 $540 \mathrm{~nm}$ 에서 흡 광도를 측정하였다. 양성대조군으로 ascorbic acid를 사용하 였으며 단백질 농도는 $\mathrm{BCA}$ 방법에 의해 정량하였다(Walker, 1994).

\section{Lipid peroxidation 측정}

울릉도 5 종이 지질 과산화물 생성에 미치는 영향을 확인하
기 위하여 Youn 등(2015)의 방법을 변형하여 사용하였다. 배 양시킨 HepG2 세포를 $1 \times 10^{6}$ cells $/ \mathrm{mL}$ 의 농도로 6-well plate 에 분주하고 24 시간 배양 후, 각 well에 $0.2 \mathrm{mg} / \mathrm{mL}$ 시료, 1 $\mathrm{mM} \mathrm{H}_{2} \mathrm{O}_{2}$ 및 $1 \mathrm{mM} \mathrm{FeSO}$ 를 처리하여 24시간 반응시켰다. 산화스트레스가 유도된 세포는 PBS로 3회 세척하고, $1 \mathrm{~mL}$ PBS를 첨가하여 scraper로 회수 후, $500 \mu \mathrm{L}$ 의 $25 \%$ trichloroacetic acid(TCA)와 $0.67 \% \mathrm{TBA}$ 를 첨가하여 $95^{\circ} \mathrm{C}$ 에서 30 분간 가열하였다. 그 후 $15: 1$ 비율의 $n$-butanol:pyrimidine $625 \mu \mathrm{L}$ 를 첨가하고, 원심분리 $(13,000 \mathrm{rpm}, 5 \mathrm{~min})$ 시킨 다음, 상등액을 취하여 $532 \mathrm{~nm}$ 에서 흡광도를 측정하였다.

\section{통계처리}

모든 실험은 3회 이상 반복 실시하였으며, 본 실험 연구에 서 얻어진 모든 측정치는 SPSS program(ver. 19.0, SPSS Inc., Chicago, USA)을 이용하여 ANOVA를 실시하고, Tukey's multiple range test로 각 군의 평균 차이에 대한 사후 검정을 하였으며, $\mathrm{p}<0.05$ 수준에서 유의차 검정을 실시하였다.

\section{결과 및 고찰}

\section{울릉도산 식물의 추출 수율, 총폴리페놀 및 총플라보노이드 함량}

울릉도산 식물 5 종을 $70 \%$ 에탄올로 추출하여 감압 농축 후 동결 건조한 시료의 추출 수율, 총폴리페놀 및 총플라보노 이드 함량을 계산한 결과는 Table 1에 나타냈다. Zang 등 (2018)에 따르면 물, 에탄올 및 메탄올과 같은 유기용매를 이 용한 추출 방법 중, 물은 용해도가 낮고 메탄올은 독성이 높 지만 에탄올은 폴리페놀 성분에 대한 추출 효율이 높고 독성 이 낮아 식물 추출 시 물과 에탄올의 이원 화합물을 주로 사 용한다고 보고되었다. 또한, 기존의 섬초롱꽃 및 감탕나무 등 의 연구에서 여러 용매 추출물 중 $70 \%$ 에탄올 추출물의 항산 화 활성 및 플라보노이드 함량이 가장 높다고 보고되어 본 실험에서도 $70 \%$ 에탄올을 이용하였다(Cho 등, 2007; Kim 등, 2018). 울릉도산 식물의 $70 \%$ 에탄올 추출물의 추출 수율 은 섬초롱꽃(32.6\%), 섬나무딸기(24.6\%), 감탕나무(16.8\%), 낭아초 $(14.8 \%)$, 솔송나무 $(12.5 \%)$ 순으로 나타났다. 섬초롱꽃 은 가장 높은 추출 수율을 나타냈으며, 섬초롱꽃이 속한 Campanula 종 중 Campanula glomerata L.과 Campanula olympica Boiss. 추출물의 추출 수율은 각각 2.99 및 $2.87 \%$ 로, 본 논문의 5 가지 울릉도산 식물의 추출 수율이 훨씬 높음 을 확인하였다(Usta 등, 2014). 또한, Kim 등(2012)의 보고에 따르면 섬초롱꽃 $80 \%$ 에탄올 추출물의 추출 수율은 $35.2 \%$ 로 본 논문의 섬초롱꽃 $70 \%$ 에탄올 추출물 추출 수율이 $32.6 \%$ 인 것과 비교하여 둘 다 높은 수율을 지님을 확인하였 
Table 1. Contents of total polyphenols and total flavonoids on five plants from Ulleung island

\begin{tabular}{|c|c|c|c|}
\hline Samples & $\begin{array}{l}\text { Extraction yield } \\
(\%) \text { Samples }\end{array}$ & $\begin{array}{l}\text { Total polyphenols } \\
\text { (mg GAE/g) }\end{array}$ & $\begin{array}{l}\text { Total flavonoids } \\
\text { (mg NAE/g) }\end{array}$ \\
\hline Campanula takesimana Nakai & $32.45 \pm 2.96^{\mathrm{al})}$ & $56.99 \pm 0.76^{\mathrm{e}}$ & $85.19 \pm 3.81^{\mathrm{e}}$ \\
\hline Ilex integra Thunb. & $16.93 \pm 1.84^{\mathrm{c}}$ & $279.76 \pm 6.40^{\mathrm{b}}$ & $270.70 \pm 6.33^{\mathrm{a}}$ \\
\hline Indigofera pseudotinctoria Matsum. & $15.00 \pm 0.50^{\mathrm{c}}$ & $116.87 \pm 2.78^{\mathrm{d}}$ & $139.29 \pm 5.18^{\mathrm{d}}$ \\
\hline Rubus takesimensis Nakai & $24.48 \pm 2.73^{\mathrm{b}}$ & $296.55 \pm 10.24^{\mathrm{a}}$ & $232.26 \pm 8.40^{\mathrm{b}}$ \\
\hline Tsuga sieboldii & $13.53 \pm 1.68^{\mathrm{c}}$ & $172.77 \pm 2.73^{\mathrm{c}}$ & $168.11 \pm 2.22^{\mathrm{c}}$ \\
\hline
\end{tabular}

${ }^{1)}$ All values represent mean $\pm \mathrm{SD}(\mathrm{n}=3$ ). Values with different letters are significantly different by Tukey's multiple range test ( $<<0.05$ ).

으며, $2.6 \%$ 차이는 추출 용매 차이에 따른 것으로 판단된다.

식물체에 함유되어 있는 페놀 화합물들은 항산화, 항암, 고 혈압 억제 등의 다양한 생리활성을 가지는 것으로 보고되었 다(Rice-Evans 등, 1997). 총 폴리페놀 함량은 섬나무딸기 (296.55 mg GAE/g)>감탕나무(279.76 mg GAE/g)>솔송나무 (172.77 mg GAE/g)>낭아초(116.87 mg GAE/g)>섬초롱꽃 (56.99 mg GAE/g) 순으로 나타났다(Table 1). 섬나무딸기가 속한 Rubus 종은 ellagic acid, tormentic acid, euscaphic acid, miquelianin 및 isoquercitrin 등 많은 폴리페놀 성분을 함유하 는 것으로 보고되었으며, 본 논문에서도 가장 높은 폴리페놀 함량을 나타냈다(Kim 등, 2014). 또한, R. fraxinifolius, $R$. rosifolius 및 $R$. fruticosus의 폴리페놀 함량이 각각 39.0, 80.62 및 $7.84 \mathrm{mg} \mathrm{GAE} / \mathrm{g}$ 으로 나타난 것에 비해 본 논문의 섬나무딸기, 감탕나무 및 솔송나무 등이 2 배 이상 더 높은 폴 리페놀 함량을 확인하였으며, 이에 따른 강력한 항산화 효능 이 나타날 것으로 추측된다.

플라보노이드는 폴리페놀에 속하는 식물색소로, 폴리페놀 과 마찬가지로 활성산소종을 효과적으로 제거하여 항산화능 이 높다고 알려져 있으며, 항바이러스, 항염증, 항암 효과가 있는 것으로 알려져 있다(Pietta, 2000). 총플라보노이드 함량 은 감탕나무 $(270.70 \mathrm{mg} \mathrm{NAE} / \mathrm{g})$, 섬나무딸기(232.26 mg $\mathrm{NAE} / \mathrm{g}$ ), 솔송나무(168.11 mg NAE/g), 낭아초(139.29 mg $\mathrm{NAE} / \mathrm{g})$ 및 섬초롱꽃 $(85.19 \mathrm{mg} \mathrm{NAE} / \mathrm{g})$ 순으로 나타났다 (Table 1). 기존의 연구에 따르면 낭아초가 속한 Indigofera종 은 quercetin, flavonol glycoside, kaempferol 등의 플라보노 이드 성분을 지니며, 특히 I. nigritana 및 I. macrocalyx는 $96.3 \mathrm{mg} / \mathrm{g}, 92.3 \mathrm{mg} / \mathrm{g}$ 의 높은 플라보노이드 함량과 이에 따 른 높은 항산화 활성과 지질 과산화 억제 활성이 보고되었다 (Bakasso 등, 2008; Rahman 등, 2018). 본 연구에서는 기존 에 발표된 Indigofera종보다 낭아초의 플라보노이드 함량이 높음을 확인하였고, 감탕나무, 섬나무딸기 및 솔송나무가 낭 아초보다 각각 $1.94,1.67$ 및 1.21 배 높은 플라보노이드 함량 을 지님을 확인하였다. 따라서 울릉도산 식물 5 종의 높은 폴
리페놀 및 플라보노이드 함량에 따른 높은 항산화 효능 및 지질 과산화 억제 효능이 나타날 것으로 추측된다. 울릉도산 식물 5종 중 폴리페놀 함량은 섬나무딸기, 플라보노이드 함 량은 감탕나무에서 제일 높게 나타났는데, 이는 폴리페놀을 구성하는 성분 중 비 플라보노이드에 속하는 ellagic acid, hydroxy benzoic acid 및 hydroxycinnamic acid 등과 그 유도 체인 stilbene, phenolic alcohol 등의 다양한 영향으로 함량에 다소 차이가 있을 것으로 판단된다(Kim 등, 2016).

\section{울릉도산 식물의 항산화 활성}

$\mathrm{DPPH}, \mathrm{ABTS}, \mathrm{FRAP}$ 및 ORAC 방법을 이용하여 울릉도 산 식물 5 종의 항산화 활성을 측정한 결과는 Table 2 에 나타 냈다. DPPH는 비교적 안정한 free radical로 폴리페놀 및 플 라보노이드와 같은 생리활성 성분들로부터 수소나 전자를 받 아 환원될 때 보라색이 탈색되어지는 원리를 이용하며, 비교 적 짧은 시간 내에 항산화능을 측정할 수 있어 널리 사용되고 있는 방법이다(Dontha, 2016). DPPH 라디칼 소거능의 $\mathrm{IC}_{50}$ 값은 섬초롱꽃, 감탕나무, 낭아초, 섬나무 딸기 및 솔송나무 에서 각각 $3.85,0.62,0.93,0.30$ 및 $0.46 \mathrm{mg} / \mathrm{mL}$ 로 섬나무딸 기에서 가장 높은 항산화능을 확인하였다. 울릉도산 5 종 추 출물에 비해 양성대조구인 ascorbic acid의 $\mathrm{IC}_{50}$ 값은 0.07 $\mathrm{mg} / \mathrm{mL}$ 로 높은 DPPH 라디칼 소거능을 보였다(Table 2). Kivi 와 Sartipnia 등(2014)은 섬나무딸기가 속한 Rubus 종의 DPPH 라디칼 소거능 결과, 물 추출물에서 $\mathrm{IC}_{50}$ 값 $0.23-0.16 \mathrm{mg} / \mathrm{mL}$, 메탄올 추출물에서 $\mathrm{IC}_{50}$ 값 $0.45-0.38 \mathrm{mg} / \mathrm{mL}$ 로 높은 항산화 활성이 보고되었으며 Lee 등(2014)에 의하면 Rubus 추출물 들에서 총폴리페놀 함량이 높은 시료일수록 $\mathrm{DPPH}$ 라디컬 소거 활성이 높았다고 보고되었다. 본 연구에서도 총 폴리페 놀 함량이 가장 높았던 섬나무딸기 추출물의 DPPH 라디칼 소거 활성이 가장 높은 것으로 나타났으므로 상관관계가 있 음을 확인하였다.

ABTS 라디칼 소거능은 potassium persulfate와의 반응에 의해 생성된 $\mathrm{ABTS}^{+}$가 시료 내의 항산화 물질에 의해 제거되 
Table 2. Antioxidant activities of five plants from Ulleung island

\begin{tabular}{|c|c|c|c|c|}
\hline \multirow{2}{*}{ Samples } & DPPH & ABTS & \multirow{2}{*}{$\frac{\text { FRAP }}{\mu \mathrm{mol} \mathrm{FeSO}_{4} / \mathrm{g}}$} & ORAC \\
\hline & \multicolumn{2}{|c|}{$\mathrm{IC} 50(\mathrm{mg} / \mathrm{mL})$} & & mmol TE/g \\
\hline Campanula takesimana Nakai & $3.85 \pm 0.85^{\mathrm{al})}$ & $4.33 \pm 0.54^{\mathrm{a}}$ & $35.57 \pm 1.33^{\mathrm{d}}$ & $1.45 \pm 0.07^{\mathrm{a}}$ \\
\hline Ilex integra Thunb. & $0.62 \pm 0.00^{\mathrm{b}}$ & $0.88 \pm 0.16^{\mathrm{ab}}$ & $314.70 \pm 3.22^{\mathrm{a}}$ & $1.47 \pm 0.23^{\mathrm{a}}$ \\
\hline Indigofera pseudotinctoria Matsum. & $0.93 \pm 0.02^{\mathrm{b}}$ & $1.85 \pm 0.66^{\mathrm{a}}$ & $182.39 \pm 0.57^{\mathrm{c}}$ & $1.47 \pm 0.16^{\mathrm{a}}$ \\
\hline Rubus takesimensis Nakai & $0.30 \pm 0.03^{\mathrm{b}}$ & $0.33 \pm 0.02^{\mathrm{b}}$ & $318.61 \pm 2.57^{\mathrm{a}}$ & $1.74 \pm .0 .12^{\mathrm{a}}$ \\
\hline Tsuga sieboldii & $0.46 \pm 0.15^{\mathrm{b}}$ & $0.49 \pm 0.26^{\mathrm{b}}$ & $279.11 \pm 4.18^{\mathrm{b}}$ & $1.33 \pm 0.27^{\mathrm{a}}$ \\
\hline Ascorbic acid & $0.07 \pm 0.00^{\mathrm{b}}$ & $0.19 \pm 0.32^{\mathrm{b}}$ & $314.64 \pm 4.09^{\mathrm{a}}$ & $1.23 \pm 0.74^{\mathrm{b}}$ \\
\hline
\end{tabular}

${ }^{1)}$ All values represent mean $\pm \mathrm{SD}(\mathrm{n}=3)$. Values with different letters are significantly different by Tukey's multiple range test $(\mathrm{p}<0.05)$.

어 탈색되는 것을 이용한 항산화능 측정 방법이다(Dontha, 2016). 울릉도산 식물의 $\mathrm{ABTS}$ 라디칼 소거 활성의 $\mathrm{IC}_{50}$ 값은 섬초롱꽃 $(4.33 \mathrm{mg} / \mathrm{mL})$, 감탕나무 $(0.88 \mathrm{mg} / \mathrm{mL})$, 낭아초 $(1.85$ $\mathrm{mg} / \mathrm{mL})$, 섬나무딸기 $(0.33 \mathrm{mg} / \mathrm{mL})$ 및 솔송나무 $(0.49 \mathrm{mg} / \mathrm{mL})$ 로 나타났다(Table 2). 양성 대조군인 ascorbic acid의 $\mathrm{IC}_{50}$ 값 은 $0.19 \mathrm{mg} / \mathrm{mL}$ 로 DPPH와 마찬가지로 5 종 추출물보다 높은 ABTS 라디칼 소거능을 확인하였다. Kim 등(2012)은 섬초롱 꽃의 물 추출물과 핵산 추출물 $0.5 \mathrm{mg} / \mathrm{mL}$ 에서 $\mathrm{ABTS}$ 라디칼 소거능은 각각 $6.82 \%$ 및 $14.46 \%$ 로 나타났으며, $\mathrm{ABTS}$ 라디 칼 소거능이 높은 추출물이 DPPH 및 FRPAP에서도 높은 항 산화 효과를 지닌다고 보고하였다. 본 실험에 사용된 섬초롱 꽃 $70 \%$ 에탄올 추출물은 $0.5 \mathrm{mg} / \mathrm{mL}$ 에서 $10.55 \%$ 소거능을 보였으며, 이는 추출 용매, 추출 온도 등의 영향을 받아 각 연구 결과가 다소 차이가 있을 것으로 판단된다. 또한, 섬나 무딸기, 솔송나무 및 감탕나무 추출물 $0.5 \mathrm{mg} / \mathrm{mL}$ 에서도 $59.45 \%, 44.85 \%, 42.28 \%$ 의 $\mathrm{ABTS}$ 라디칼 소거능을 보여 높 은 항산화 활성을 확인하였다.

$\mathrm{Fe}^{2+}$ 는 hydroxyl radical( $(\cdot \mathrm{OH})$ 과 superoxide $\operatorname{radical}\left(\cdot \mathrm{O}^{2-}\right)$ 등 의 생성을 촉진하며, 이러한 금속이온인자에 대한 chelating 활성이 높을수록 산화반응에 촉매작용을 감소시킬 수 있는 능력을 측정하는 지표로 이용된다(Ojha 등, 2018). 울릉도산 식물의 FRAP 라디칼 소거 활성은 섬나무딸기(318.61 $\mu \mathrm{mol}$ $\mathrm{FeSO}_{4} / \mathrm{g}$ ), 감탕나무(314.70 $\mu \mathrm{mol} \mathrm{FeSO} / \mathrm{g}$ ), 솔송나무(279.11 $\left.\mu \mathrm{mol} \mathrm{FeSO}_{4} / \mathrm{g}\right)$, 낭아초 $\left(182.39 \mu \mathrm{mol} \mathrm{FeSO}_{4} / \mathrm{g}\right)$ 그리고 섬초

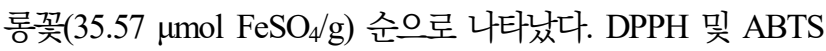
와 달리 양성대조군인 ascorbic acid(314.70 $\mu \mathrm{mol} \mathrm{FeSO}_{4} / \mathrm{g}$ ) 보다 섬나무딸기와 감탕나무에서 높은 FRAP 라디칼 소거 활성을 보여 두 가지 추출물이 금속이온에 대한 chelating 활 성이 뛰어나다고 판단된다. 감탕나무가 속한 Ilex종의 유전자 형이 다른 6가지 추출물을 LC-PDA-APCI-MS을 통해 분석 한 결과, 대표적으로 caffeoylquinic acid, rutin 및 kaempferol
등의 폴리페놀이 함유되어 있었으며, 폴리페놀 함량이 높은 Ilex종일수록 ABTS, FRAP에서 가장 높은 항산화활성을 보 였다. 또한, 폴리페놀 함량과 항산화 활성 간의 상관관계를 정량화하기 위해 Pearson 상관관계 분석을 한 결과, 폴리페 놀 함량과 $\mathrm{ABTS}, \mathrm{FRAP}$ 및 DPPH 모두에서 양의 상관관계 를 확인하였다(Zhu 등, 2009). 본 연구 결과, 총 페놀 함량이 가장 높은 섬나무딸기의 추출물에서 $\mathrm{DPPH}, \mathrm{ABTS}, \mathrm{FRAP}$ 및 ORAC assay 항산화 활성이 가장 높게 측정되어, 각 추출 물이 함유하고 있는 총폴리페놀 화합물의 함량이 항산화 활 성에 영향을 미친다는 보고와 일치하였다.

ORAC assay는 일정 시간이 지남에 따라 peroxyl radical 에 의해 손상되어 발색되는 형광 값을 측정하여 시료의 항산 화능을 측정하는 실험 방법이다(Ojha 등, 2018). 섬초롱꽃, 감탕나무, 낭아초, 섬나무딸기 및 솔송나무 추출물의 ORAC value를 측정한 결과, 각각 $1.45,1.47,1.47,1.74$ 및 1.33 $\mathrm{mmol} \mathrm{TE} / \mathrm{g}$ 으로 나타났다. 양성대조군인 ascorbic $\operatorname{acid}(1.33$ $\mathrm{mmol} \mathrm{TE} / \mathrm{g}$ )보다 5 종의 추출물이 모두 높은 ORAC 항산화능 을 보여 DPPH와 달리 시료가 장시간 반응에 의한 항산화능 이 높다고 판단된다. Wang과 $\operatorname{Lin}(2000)$ 의 보고에 따르면 섬 나무딸기가 속한 Rubus 종 추출물들의 ORAC 활성을 스크 리닝한 결과, 건조한 시료에서는 $0.035-0.162 \mathrm{mmol} \mathrm{TE} / \mathrm{g}$, 건 조하지 않은 시료에서는 $0.007-0.033 \mathrm{mmol} \mathrm{TE} / \mathrm{g}$ 을 나타내었 다. 이에 비해 본 논문의 울릉도산 식물 5 종의 ORAC 평균은 $1.49 \mathrm{mmol} \mathrm{TE} / \mathrm{g}$ 으로 훨씬 높은 수치를 나타내 항산화 효과 가 높은 천연 자원으로 이용이 가능할 것으로 판단된다. 폴리 페놀 함량이 가장 높았던 섬나무딸기의 ORAC value가 1.74 $\mathrm{mmol} \mathrm{TE} / \mathrm{g}$ 으로 가장 높게 나왔으나, 플라보노이드 함량이 가장 높았던 감탕나무의 ORAC value는 $1.47 \mathrm{mmol} \mathrm{TE} / \mathrm{g}$ 으 로 다른 종과 비슷한 결과를 보였다. 따라서 폴리페놀류 중 플라보노이드뿐만 아니라 비플라보노이드 역시 ORAC value 에 영향을 미친다는 보고와 일치하였다(Madrigal-Carballod 
등, 2009). 본 논문의 DPPH, ABTS, FRAP 및 ORAC assay 실험결과, 울릉도산 식물 5 종의 항산화 활성이 모두 우수함 을 확인하였다.

\section{울릉도산 식물의 세포 독성 평가}

울릉도산 식물인 섬초롱꽃, 감탕나무, 낭아초, 섬나무딸기 및 솔송나무 추출물에 의한 $\mathrm{HepG} 2$ 세포의 생존율을 확인한 결과를 Fig. 1과 같이 나타내었다. 시료를 첨가하지 않은 세 포에 비해 5 종 추출물 모두 $0.8 \mathrm{mg} / \mathrm{mL}$ 에서 세포 생존율이 감소하였으나 통계적으로 유의한 차이는 나타나지 않았다 $(\mathrm{p}<0.05) . \mathrm{Kim}$ 등(2018)의 보고에 따르면 제주도 자생식물 중 감탕나무과 추출물의 Raw 264.7 세포에 대해 $0.2 \mathrm{mg} / \mathrm{mL}$ 농도에서 약 $100 \%$ 의 생존율을 나타냈으며, $\mathrm{Kim}$ 등(2019)은 섬나무딸기와 가장 유사한 종인 산딸기속 식물이 Raw 264.7 세포에 대해 $0.2 \mathrm{mg} / \mathrm{mL}$ 농도에서 $86 \%$ 의 세포 생존율, $57.1 \%$ 의 $\mathrm{NO}$ 생성량 억제 효과를 보고하였다. 따라서 본 논문 에서는 추출물의 농도를 수율과 활성을 고려하여 이하 모든 세포 실험에서 $0.2 \mathrm{mg} / \mathrm{mL}$ 농도로 진행하였다.

\section{울릉도산 식물의 세포 지질 축적 및 중성지방 함량 감소 효과}

울릉도산 식물의 지질축적억제 활성을 평가하기 위하여 HepG2 세포에 OA를 이용하여 지방 생성을 유도한 후 ORO 염색법으로 평가하였다. ORO 염색 시약은 세포 내 지질과 결합하며, 염색된 세포의 붉은색이 강할수록 세포 내 지질 축 적이 많이 이루어졌음을 의미한다(Yao 등, 2011). 분화된 $\mathrm{HepG} 2$ 세포 $\mathrm{ORO}$ 로 염색하고 광학 현미경을 통해 관찰 후 정량하였다(Fig. 2A-B). 결과, $\mathrm{OA}$ 만 처리한 세포는 $\mathrm{OA}$ 를 처 리하지 않은 세포에 비해 지질 형성이 활발하게 유발된 것을 관찰하였으며, 이를 정량한 결과, 지질 축적률이 5.9 배 증가하 였다 $(\mathrm{p}<0.05)$. 울릉도산 식물의 처리한 세포는 각각 섬초롱 꽃(46.20\%), 감탕나무(46.20\%), 낭아초(51.35\%), 섬나무딸 기(61.91\%) 및 솔송나무(49.89\%)의 지질 축적률 억제 효과 를 확인하였다 $(\mathrm{p}<0.05)$. 양성대조군으로 쓰인 ascorbic acid 의 지질 축적 억제 효과는 $67.33 \%$ 로 모든 추출물보다 높았으 나, 섬나무딸기와는 유의적 차이를 보이지 않아 울릉도산 5 종 중 섬나무딸기의 지질 축적 억제 효과가 가장 높음을 확인 하였다. Forbes 등(2017)은 항산화 활성이 높을수록 HepG2 세포에서 지질 축적률 억제 효과가 증가한다고 보고하였으며, Pisonero 등(2015)은 다양한 플라보노이드 성분인 quercetin, naringenin 등이 지방산 산화 및 지질 합성 경로를 조절함으 로써 지방간증을 억제하고, 비알코올성 지방간질환을 개선한 다고 보고하였다. 울릉도산 식물 5 종 중 항산화 활성이 가장 높았던 섬나무딸기의 지질 축적 억제율이 가장 높은 결과를

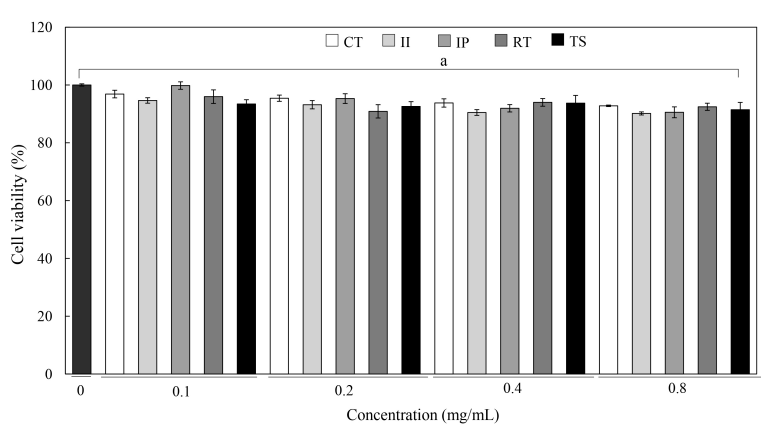

Fig. 1. Effect of five plants from Ulleung island on cell viability in HepG2 cell.

CT, Campanula takesimana Nakai; II, Ilex integra Thunb.; IP, Indigofera pseudotinctoria Matsum; RT, Rubus takesimensis Nakai; TS, Tsuga sieboldii.

Cells were incubated with extracts at the concentration of 100, 200, 400,800 , and $1,000 \mu \mathrm{g} / \mathrm{mL}$ for $24 \mathrm{~h}$. Cell viability was measured by MTT assay. Data are expressed as percent growth rate of cells cultured in the presence of extracts compared with untreated control cells, taken as $100 \%$. Results were presented as mean $\pm \mathrm{SD}(\mathrm{n}=3)$. Different letters indicate significant difference between means at $\mathrm{p}<0.05$ by Tukey's multiple range test.

통해 지질 축적이 항산화 효과를 나타내는 폴리페놀 물질과 연관됨을 확인하였다.

체내에서 중성 지방은 포도당과 함께 세포의 중요한 에너 지원으로 사용되지만 간세포의 중성지방이 과도하게 축적될 경우 지방간으로 인한 간기능 저하, 간경화, 간암 또는 다양 한 만성 질환의 원인이 된다(Kawano과 Cohen, 2013). 따라 서 본 연구에서는 $\mathrm{HepG} 2$ 에 $\mathrm{OA}$ 를 처리하여 지방 생성을 유 도 후 울릉도산 식물 추출물의 중성 지방 함량을 측정하여 Fig. $2 \mathrm{C}$ 에 제시하였다. $\mathrm{OA}$ 를 처리하지 않은 $\mathrm{HepG} 2$ 세포에 서 중성 지방 함량은 $42.02 \mathrm{mg} / \mathrm{dL}$ 로 나타났으며, $\mathrm{OA}$ 만 처리 한 세포에서 중성 지방 함량은 $159.70 \mathrm{mg} / \mathrm{dL}$ 로 나타나 중성 지방 생성이 3.78 배 증가됨을 확인하였다 $(\mathrm{p}<0.05)$. 울릉도산 식물을 처리한 세포의 중성지방 함량은 섬나무딸기(39.27 $\mathrm{mg} / \mathrm{dL})$, 솔송나무 $(42.48 \mathrm{mg} / \mathrm{dL})$, 낭아초 $(47.24 \mathrm{mg} / \mathrm{dL})$, 섬초 롱꽃 $(57.11 \mathrm{mg} / \mathrm{dL})$, 감탕나무 $(57.61 \mathrm{mg} / \mathrm{dL})$ 순으로 $\mathrm{OA}$ 만 처 리한 세포와 비교하여 모두 $100 \mathrm{mg} / \mathrm{dL}$ 이상억제 효과를 나타 냈다. 양성대조군인 ascorbic acid의 중성 지방 함량은 38.60 $\mathrm{mg} / \mathrm{dL}$ 로 추출물 5 종보다 억제 효과가 높으나 유의적인 차이 는 보이지 않아 울릉도산 5종 추출물의 우수한 중성 지방 억 제 활성을 확인하였다. Sun 등(2019)의 보고에 따르면 산화 스트레스의 과도한 증가는 adipokine의 생성 이상을 초래하 여 간의 c-reactive protein을 증가시켜 대사질환을 유발한다. 또한, Yang 등(2018)은 연구를 통해 항산화 성분이 지방간 관련인자인 AMP-activated protein kinase 및 Acetyl-CoA carboxylase를 인산화 시켜 지질 대사 억제를 통한 중성 지방 생성억제 효과를 지닌다고 보고하였다. 본 연구 결과, 항산화 
(A)
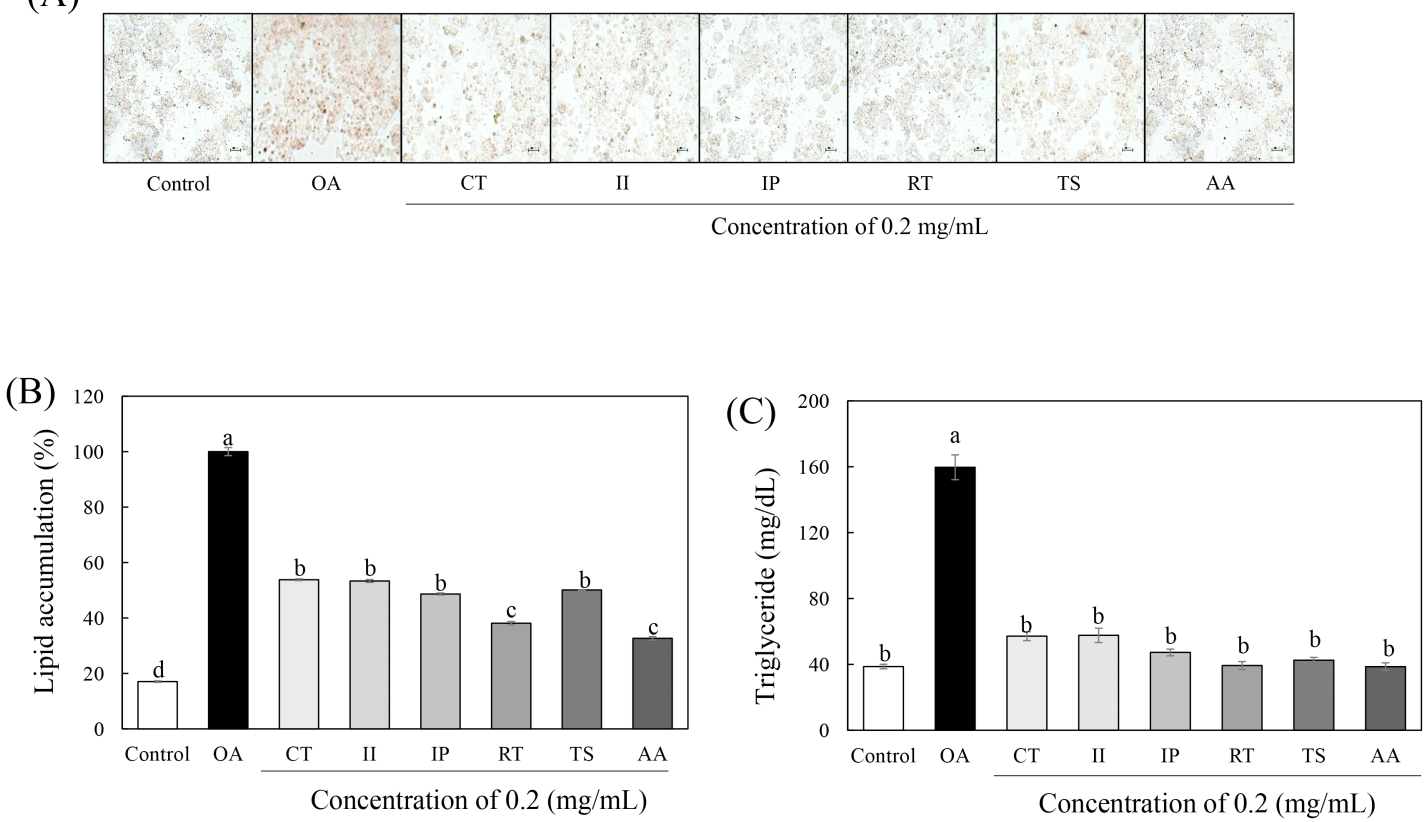

Fig. 2. Effect of five plants from Ulleung island on lipid accumulation in HepG2 cell.

(A) Oil Red O staining, (B) Lipid accumulation and (C) Triglyceride content.

OA, oleic aicd; CT, Campanula takesimana Nakai; II, Ilex integra Thunb.; IP, Indigofera pseudotinctoria Matsum; RT, Rubus takesimensis Nakai; TS, Tsuga sieboldii; AA, ascorbic aicd.

Lipid accumulation and triglyceride contents in HepG2 cell was evaluated by Oil Red O staining and triglyceride assay kit. Results were presented as mean $\pm \mathrm{SD}(\mathrm{n}=3)$. Different letters indicate significant difference between means at $\mathrm{p}<0.05$ by Tukey's multiple range test.

활성이 높았던 울릉도산 식물 5 종의 중성 지방 생성이 모두 유의적으로 낮아졌으며, 항산화 활성이 중성 지방 생성에 영 향을 미친다고 예측된다. 이를 확인하기 위해 분자생물학적 인 후속 연구가 필요할 것으로 판단된다.

\section{울릉도산 식물의 지질 과산화물 생성억제 활성}

지질 과산화는 조직 내 ROS 발생으로 인한 인지질 막 내 불포화 지방산의 수소를 탈취함으로써 지질 과산화(lipid peroxidation)의 연쇄반응이 진행되고, 최종 부산물로 malondialdehyde(MDA) 등의 지질 과산화물을 생성한다. 이러한 부산물들은 간세포 손상 및 단백질 변화 등을 유발시켜 간독 성을 나타내며, hepatic lipid의 alkyl기 또는 간세포 핵의 $\mathrm{DNA}$ 와 공유결합을 하여 괴사를 일으킨다고 보고되었다 (Poli 등, 1987). 이에, 본 실험에서는 추출물의 지질 과산화물 생성 억제 효과와 산화스트레스를 유발한 HepG2세포에서의 지질 과산화물 생성 억제 효과를 각각 Table 3과 Fig. 3에 나

Table 3. Inhibitory effect of lipid peroxidation on five plants from Ulleung island

\begin{tabular}{|c|c|c|c|c|c|}
\hline \multirow{2}{*}{ Samples } & \multicolumn{5}{|c|}{ Concentration $(\mathrm{mg} / \mathrm{mL})$} \\
\hline & 0.0625 & 0.125 & 0.25 & 0.5 & 1 \\
\hline Campanula takesimana Nakai & $6.91 \pm 1.57^{\mathrm{d} 1)}$ & $7.41 \pm 0.11^{\mathrm{c}}$ & $8.58 \pm 5.22^{\mathrm{c}}$ & $11.75 \pm 4.22^{\mathrm{b}}$ & $17.63 \pm 9.40^{\mathrm{b}}$ \\
\hline Ilex integra Thunb. & $23.51 \pm 0.25^{\mathrm{c}}$ & $25.03 \pm 1.55^{\mathrm{b}}$ & $27.45 \pm 3.20^{\mathrm{bc}}$ & $29.20 \pm 4.59^{\mathrm{ab}}$ & $33.73 \pm 5.80^{\mathrm{ab}}$ \\
\hline Indigofera pseudotinctoria Matsum. & $25.31 \pm 1.85^{\mathrm{c}}$ & $28.39 \pm 2.48^{\mathrm{b}}$ & $34.06 \pm 5.27^{\mathrm{abc}}$ & $36.86 \pm 4.64^{\mathrm{ab}}$ & $34.80 \pm 0.28^{\mathrm{ab}}$ \\
\hline Rubus takesimensis Nakai & $42.34 \pm 10.37^{\mathrm{ab}}$ & $43.43 \pm 0.12^{\mathrm{a}}$ & $44.46 \pm 1.71^{\mathrm{abc}}$ & $47.83 \pm 6.47^{\mathrm{a}}$ & $52.51 \pm 12.47^{\mathrm{ab}}$ \\
\hline Tsuga sieboldii & $47.75 \pm 2.77^{\mathrm{a}}$ & $49.74 \pm 2.36^{\mathrm{a}}$ & $50.69 \pm 7.82^{\mathrm{ab}}$ & $53.84 \pm 2.64^{\mathrm{a}}$ & $56.87 \pm 7.53^{\mathrm{ab}}$ \\
\hline Ascorbic acid & $31.84 \pm 1.99^{\mathrm{bc}}$ & $32.85 \pm 2.05^{\mathrm{b}}$ & $58.02 \pm 2.54^{\mathrm{a}}$ & $61.45 \pm 4.98^{\mathrm{a}}$ & $65.08 \pm .4 .98^{\mathrm{a}}$ \\
\hline
\end{tabular}

\footnotetext{
${ }^{1)}$ All values represent means \pm SD $(n=3)$. Values with different letters are significantly different by Tukey's multiple range test ( $\left.<<0.05\right)$.
} 


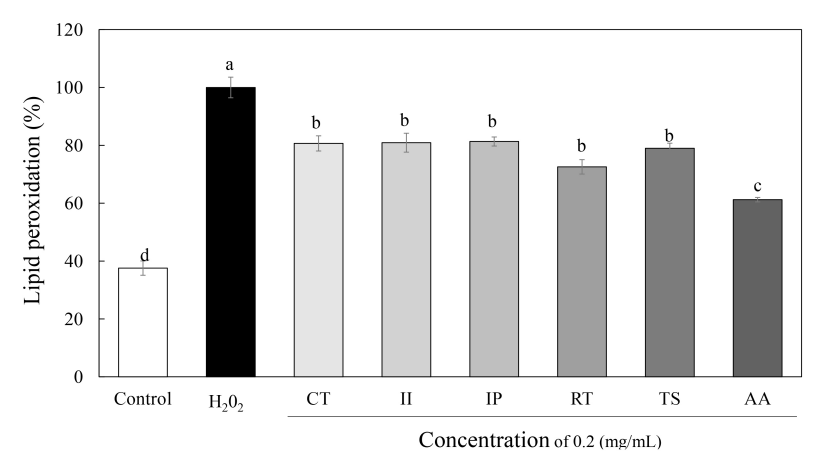

Fig. 3. Effect of five plants produced in Ulleung island on lipid peroxidation in HepG2 cell.

CT, Campanula takesimana Nakai; II, Ilex integra Thunb.; IP, Indigofera pseudotinctoria Matsum; RT, Rubus takesimensis Nakai; TS, Tsuga sieboldii; AA, ascorbic acid.

Lipid peroxidation in HepG2 cell was evaluated by TBA assay. Results were presented as mean $\pm \mathrm{SD}(\mathrm{n}=3)$. Different letters indicate significant difference between means at $\mathrm{p}<0.05$ by Tukey's multiple range test.

타내었다. 불포화 지방산인 linoleic acid를 이용한 TBA 방법 으로 울릉도산 식물 5 종의 항산화 활성을 측정한 결과, 1 $\mathrm{mg} / \mathrm{mL}$ 농도의 시료 첨가구에서는 시료 무첨가구에 비해 솔 송나무 $(56.87 \%)>$ 섬나무딸기(52.51\%) > 낭아초 $(34.80 \%)$ $>$ 감탕나무 $(33.75 \%)>$ 섬초롱꽃 $(17.63 \%)$ 순으로 억제율을 보였으며, 각각의 5종 추출물은 농도 의존적으로 지질 과산 화물 생성을 억제하였다(Fig. 3). 총 폴리페놀 함량이 높았던 섬나무딸기 추출물은 가장 낮은 농도인 $62.5 \mu \mathrm{g} / \mathrm{mL}$ 에서도 $40 \%$ 이상의 지질 과산화물 생성 억제 활성을 보였으며, 모든 추출물에서 농도의존적으로 효과가 나타나, 폴리페놀 함량이 지질 과산화물 생성에 영향을 미친다고 한 Liu와 $\operatorname{Luo(2019)}$ 의 보고와 일치한 결과를 확인하였다. 양성대조군인 ascorbic acid의 지질 과산화물 생성 억제율은 $125 \mu \mathrm{g} / \mathrm{mL}$ 에서 $32.85 \%$ 로 섬나무딸기(43.43\%) 및 솔송나무(49.74\%)에서 더 높은 효과를 보여 두가지 추출물의 효과적인 지질 과산화물 억제 활성을 확인하였다.

산화 스트레스로 인한 세포 손상의 증거로 생성된 지질 과 산화 생성물에 대한 울릉도산 식물의 억제 효과를 확인한 결 과, $\mathrm{HepG} 2$ 세포에 $\mathrm{H}_{2} \mathrm{O}_{2}$ 를 단독 처리한 세포는 $\mathrm{H}_{2} \mathrm{O}_{2}$ 를 처리 하지 않은 세포에 비해 지질 과산화물이 $62.43 \%$ 증가하였다. 세포에 울릉도산 식물 5 종을 처리한 경우는 $\mathrm{H}_{2} \mathrm{O}_{2}$ 단독 처리 세포와 비교하여 섬나무딸기 $(27.43 \%)>$ 솔송나무 $(21.00 \%)>$ 섬초롱꽃(19.33\%) > 감탕나무(19.09\%) > 낭아초(18.66\%) 순으로 유의한 지질 과산화물 생성 억제 효과를 보였다. 양성 대조군인 ascorbic acid의 지질 과산화물 억제율은 $38.78 \%$ 를 보여 추출물 5 종보다 높은 활성을 확인하였다. 한편, 본 연구 에서 가장 높은 폴리페놀 함량을 나타냈던 섬나무딸기 추출 물의 지질 과산화물 생성 억제 활성은 다른 추출물들에 비해
유의적인 차이를 나타내지는 않았다. 이는 지질 과산화물 생 성에 식물 추출물의 폴리페놀 외 당단백질, 단백질 효소, 지 방산 성분 등에 따라 차이가 생겼을 것으로 판단된다(Niki emd, 2005).

이상의 결과를 통해, 울릉도산 식물 5 종의 항산화 활성을 기반으로 한 지질 과산화물 및 지질 축적률 억제 효과를 확인 하였으며, 이를 식품 소재로 활용하였을 시 간세포의 지질 축 적 억제 효과를 가질 것으로 사료된다. 향후 울릉도산 식물 5 종을 건강 식품 소재로 이용하기 위해 원료의 기능성, 표준 화, 안전성에 대한 추가 연구가 필요하다고 판단된다(Kim 등, 2012).

\section{요 약}

본 연구는 울릉도산 식물 5 종의 생리효능을 체계적으로 밝 히기 위한 기초 자료를 얻고자 HepG2 세포에서 $70 \%$ 에탄올 추출물의 항산화 및 지질 축적 효과를 검증하였다. 울릉도산 식물 5종 중 추출 수율은 섬초롱꽃이 가장 좋았으며 총폴리 페놀 함량 및 총플라보노이드 함량은 각각 섬나무딸기와 감 탕나무가 가장 높았다. 울릉도산 식물 5 종의 건강 식품 소재 로서 가치를 확인하기 위하여 항산화 활성 및 지질 축적률 억제를 확인한 결과, DPPH, ABTS, FRAP 및 ORAC에서 5 종 모두 높은 항산화 활성을 보였으며, 섬나무딸기에서 가장 강력한 항산화 활성이 나타났다. 또한, $\mathrm{OA}$ 와 $\mathrm{H}_{2} \mathrm{O}_{2}$ 를 각각 처리한 HepG2 세포에서 ORO 염색법, 중성 지방 함량 측정 및 TBA assay 결과, 울릉도산 식물 5 종 추출물 모두 지질 축적률 및 중성 지방 함량을 $50 \%$ 이상 감소시키고, 약 $17 \%$ 의 지질 과산화물을 생성을 억제시켰다. 이상의 결과로부터 본 논문이 울릉도산 식물 5종을 건강 식품 소재로 활용하기 위한 생리활성물질, 항산화 활성 및 지질 축적 억제 활성을 검토하는 기초 자료로 활용될 수 있을 것이라 사료된다.

\section{감사의 글}

본 연구는 2019년도 덕성여자대학교 교내연구비 지원 에 의해 수행되었으며 감사드립니다.

\section{Conflict of interests}

The authors declare no potential conflict of interest.

\section{ORCID}

SukJin Kim https://orcid.org/0000-0002-4906-3817

Gun-Hee Kim https://orcid.org/0000-0001-8196-7149 


\section{References}

Abenavoli L, Milic N, Luzza F, Boccuto L, De Lorenzo A. Polyphenols treatment in patients with nonalcoholic fatty liver disease. J Transl Intern Med, 5, 144-147 (2017)

Ainsworth EA, Gillespie KM. Estimation of total phenolic content and other oxidation substrates in plant tissues using Folin-Ciocalteu reagent. Nat Protoc, 2, 875- 877 (2007)

Alfadda AA, Sallam RM. Reactive oxygen species in health and disease. J Biomed Biotechnol, 2012, 936486 (2012)

Bakasso S, Lamien-Meda A, Lamien CE, Kiendrebeogo M, Millogo J, Ouedraogo AG, Nacoulma OG. Polyphenol contents and antioxidant activities of five Indigofera species (Fabaceae) from Burkina Faso. Pak J Biol Sci, 11, 1429-1435 (2008)

Chan CY, Hong JK, Cho HJ, Bae KH, Kim JS. Structure and understory species diversity of Pinus parvifloraTsuga sieboldii forest in Ulleung island. J Korean For Soc, 100, 34-41 (2011)

Cho JY, Kim HG, Yang SY, Son DM, Jang HG, Heo BG, Kim CS. Effects of the different substrates on the plant growth and mineral contents of Campanula takesimana in water culture. J Bio-Environ Control, 16, 228-232 (2007)

Cichoz-Lach H, Michalak A. Oxidative stress as a crucial factor in liver diseases. World J Gastroenterol, 7, 80828091 (2014)

Desmiaty Y, Elya B, Saputri FC, Hanafi M, Prastiwi R. Antioxidant activity of Rubus fraxinifolius Poir. and Rubus rosifolius J. Sm. leaves. J Young Pharm, 10, S93-S96 (2018)

Dissanayake DP, Abeytunga DTU, Vasudewa NS, Ratnasooriya WD. Inhibition of lipid peroxidation by extracts of Pleurotus ostreatus. Phcog Mag, 5, 266-271 (2009)

Dontha S. A review on antioxidant methods. Asian J Pharm Clin Res, 9, 14-32 (2016)

Forbes-Hernandez TY, Giampieri F, Gasparrini M, Afrin S, Mazzoni L, Cordero MD, Mezzetti B, Quiles JL, Battino M. Lipid accumulation in HepG2 cells is attenuated by strawberry extract through AMPK activation. Nutrients, 9, 621 (2017)

Garrett AR, Murray BK, Robison RA, O'Neill KL. Measuring antioxidant capacity using the ORAC and TOSC assays.
Methods Mol Biol, 594, 251-262 (2010)

Herrick TA, Perry LP. Influence of freeze acclimation procedure on survival and regrowth of container-grown Campanula takesimana Nakai. HortTechnology, 7, 43-46 (1997)

Jadeja RN, Devkar RV, Nammi S. Oxidative stress in liver diseases: Pathogenesis, prevention, and therapeutics. Oxid Med Cell Longevity, 2017, 8341286 (2017)

Kahl R, Kappus H. Toxicology of the synthetic antioxidants BHA and BHT in comparison with the natural antioxidant vitamin E. Z Lebensm Unters Forsch, 196, 329-338 (1993)

Kawano YK, Cohen DE. Mechanisms of hepatic triglyceride accumulation in non-alcoholic fatty liver disease. J Gastroenterol, 48, 434-441 (2013)

Kim HJ, Lee DJ, Ku JJ, Choi K, Park KW, Kang SH, Moon C, Lee PJ. Anti-inflammatory effect of extracts from folk plants in Ulleung island. Korean J Plant Res, 26, 169-177 (2013)

Kim MG, Oh MS, Jeon JS, Kim HT, Yoon MH. A study on antioxidant activity and antioxidant compound content by the types of tea. J Food Hyg Saf, 31, 132-139 (2016)

Kim MJ, Jung TK, Kim MH, Yoon KS. In vitro screening of Jeju island plants for cosmetic ingredients. KSBB J, 33, 76-82 (2018)

Kim MS, Kim KH, Yook HS. Antioxidative effects of Campanula takesimana Nakai extract. J Korean Soc Food Sci Nutr, 41, 1331-1337 (2012)

Kim MS, Yang KW, Kim SY. The anti-oxidant activity and anti-inflammatory effect of Rubus buergeri Miguel leaf extract. KSBB J, 34, 331-337 (2019)

Kim MY, Tapondjou LA, Park HJ. Quantitative determination of the triterpenoids and total tannin in Korean Rubus species by HPLC. Nat Prod Sci, 20, 290-295 (2014)

Kim SK, Choe HS, Lee BH. Toxicity testing methods for the development of health functional food: lesson from the drug development. Safe Food, 7, 22-28 (2012)

Kivi AR, Sartipnia N. DPPH radical scavenging activity and phenolic compound content in leaf extracts from raspberries. Annu Res Rev Biol, 4, 4174-4180 (2014)

Kwon YS, Won HM, Kim CM. Flavonoids from Indigofera pseudo-tinctoria stem. Kor J Pharmacogn, 31, 280-283 
(2000)

Lee HH, Moon YS, Yun HK, Park PJ, Kwak EJ. Contents of bioactive constituents and antioxidant activities of cultivated and wild raspberries. Kor J Hort Sci Technol, 32, 115-122 (2014)

Liu K, Luo M, Wei S. The bioprotective effects of polyphenols on metabolic syndrome against oxidative stress: evidences and perspectives. Oxid Med Cell Longevity, 2019, 6713194 (2019)

Madrigal-Carballo S, Rodriguez G, Krueger CG, Dreher M, Reed JD. Pomegranate (Punica granatum) supplements: Authenticity, antioxidant and polyphenol composition. J Funct Foods, 1, 324-329 (2009)

Niki E, Yoshida Y, Saito Y, Noguchi N. Lipid peroxidation: Mechanisms, inhibition, and biological effects. Biochem Biophys Res Commun, 338, 668-676 (2005)

Ojha K, Dubey S, Chandrakar J, Minj RA, Dehariya R, Dixit AK. A review on different methods of determination of antioxidant activity assay of herbal plants. Res J Life Sci Bioinf Pharm Chem Sci, 4, 707-730 (2018)

Olszowy M, Dawidowicz AL. Is it possible to use the DPPH and ABTS methods for reliable estimation of antioxidant power of colored compounds?. Chem Pap, 72, 393-400 (2018)

Park JS, Kim YS, Kwon WC, Nam SH, Xi H. The complete chloroplast genome of Nepal Holly, Ilex integra Thunb. (Aquifoliaceae). Mitochondrial DNA part B, 4, 12571258 (2019)

Pietta PG. Flavonoids as antioxidants. J Nat Prod, 63, 1035-1042 (2000)

Pisonero-Vaquero S, Gonzalez-Gallego J, Sanchez-Campos S, Garcia-Mediavilla MV. Flavonoids and related compounds in non-alcoholic fatty liver disease therapy. Curr Med Chem, 22, 2991-3012 (2015)

Poli G, Albano E, Dianzani MU. The role of lipid peroxidation in liver damage. Chem Phys Lipids, 45, 117-142 (1987)

Rahman TU, Zeb MA, Liaqat W, Sajid M, Hussain S, Choudhary MI. Phytochemistry and pharmacology of genus Indigofera: A review. Rec Nat Prod, 12, 1-13 (2018)

Rice-Evans C, Miller N, Paganga G. Antioxidant properties of phenolic compounds. Trends Plant Sci, 2, 152-159 (1997)
Senthilraja P, Kathiresan K. In vitro cytotoxicity MTT assay in vero, HepG2 and MCF -7 cell lines study of marine yeast. J Appl Pharm Sci, 5, 80-84 (2015)

Shi P, Du W, Wang Y, Teng X, Chen X, Ye L. Total phenolic, flavonoid content, and antioxidant activity of bulbs, leaves, and flowers made from Eleutherine bulbosa (Mill.) Urb. Food Sci Nutr, 7, 148-154 (2019)

Shimokawa H. Reactive oxygen species in cardiovascular health and disease: Special references to nitric oxide, hydrogen peroxide, and Rho-kinase. J Clin Biochem Nutr, 66, 83-91 (2020)

Spahis S, Delvin E, Borys JM, Levy E. Oxidative stress as a critical factor in nonalcoholic fatty liver disease pathogenesis. Antioxid Redox Signal, 26, 519-541 (2017)

Sun Z, Zhao M, Bian W, Ma H, Sun C. Associations of severity of fatty liver with oxidative stress, SAA, CRP and degree of cerebral arteriosclerosis in cerebral arteriosclerosis patients who have fatty liver. Int J Clin Exp Pathol, 12, 3022-3026 (2019)

Um ES, Kim YC. Effect of Samhwangsasim-tang and Daehwanghwangryunsasim-tang on palmitate-induced lipogenesis in HepG2 cells. J Korean Med, 37, 62-76 (2016)

Vijayalakshmi M, Ruckmani K. Ferric reducing anti-oxidant power assay in plant extract. Bangladesh J Pharmacol, 11, 570-572 (2016)

Walker JM. The bicinchoninic acid (BCA) assay for protein quantitation. Methods Mol Biol, 32, 5-8 (1994)

Wang SY, Lin HS. Antioxidant activity in fruits and leaves of blackberry, raspberry, and strawberry varies with cultivar and developmental stage. J Agric Food Chem, 48, 140-146 (2000)

Yao HR, Liu J, Plumeri D, Cao YB, He T, Lin L, Li Y, Jiang YY, Li J, Shang J. Lipotoxicity in HepG2 cells triggered by free fatty acids. Am J Transl Res, 15, 284-291 (2011)

Yang JP, Shin JH, Seo SH, Kim SG, Lee SH, Shin EH. Effects of antioxidants in reducing accumulation of fat in hepatocyte. Int J Mol Sci, 19, 2563 (2018)

Yang JY, Pak JH. Phylogeny of Korean Rubus (Rosaceae) based on ITS (nrDNA) and trnL/F intergenic region (cpDNA). J Plant Biol, 49, 44-54 (2006)

Yang SY, Jan HD, Nam BM, Chung GY, Lee RY, Lee JH, 
Oh BU. A florisitic study of Ulleungdo island in Korea. Korean J Pl Taxon, 45, 192-212 (2015)

Youn Y, Kim HY, Park HM, Lee SH, Park JR, Hong SG,

Kim YG. Protective effects of mulberry (Morus alba)

sugar extracts on hydrogen peroxide-induced oxidative

stress in HepG2 cell. Korean J Food Preserv, 22, 751-757 (2015)

Zhang QW, Lin LG, Ye WC. Techniques for extraction and isolation of natural products: A comprehensive review. Chin Med, 13, 20 (2018)

Zhu F, Cai YZ, Sun M, Ke J, Lu D, Corke H. Comparison of major phenolic constituents and in vitro antioxidant activity of diverse kudingcha genotypes from Ilex kudingcha, Ilex cornuta, and Ligustrum robustum. J Agric Food Chem, 57, 6082-6089 (2009) 